\title{
ALCOHOL CONSUMPTION AMONG STUDENTS IN THE LUBLIN REGION OF POLAND
}

\section{POZIOM SPOŻYCIA ALKOHOLU PRZEZ STUDIUJĄCYCH W WOJEWÓDZTWIE LUBELSKIM}

\author{
Marta Mandziuk $^{1(\mathrm{~A}, \mathrm{~B}, \mathrm{C}, \mathrm{E}, \mathrm{F})}$, Małgorzata Wasilewska $^{1(\mathrm{~A}, \mathrm{C}, \mathrm{D}, \mathrm{F})}$, Andrea Lukács ${ }^{2(\mathrm{~A}, \mathrm{C}, \mathrm{F})}$
}

\author{
${ }^{1}$ Pope John Paul II State School of Higher Education in Biała Podlaska, Poland \\ ${ }^{2}$ University of Miskolc, Hungary
}

Authors' contribution Wkład autorów:

A. Study design/planning zaplanowanie badań B. Data collection/entry zebranie danych

C. Data analysis/statistics dane - analiza i statystyki D. Data interpretation interpretacja danych E. Preparation of manuscript przygotowanie artykułu F. Literature analysis/search wyszukiwanie i analiza literatury G. Funds collection zebranie funduszy
Tables: 1

Figures: 0

References: 25

Submitted: 2019 Sep 17

Accepted: 2020 Feb 3

\section{Summary}

Background. Alcohol is a psychoactive addictive substance that is a frequent part of student life, where consumption levels can be high. This study aimed to determine the level of alcohol consumption among students in the Lublin province.

Material and methods. The study was carried out in 2018, using 700 freshmen from the Lublin province ( 456 women $-65.14 \%$ and 244 men - 34.86\%) who completed the Alcohol Use Disorders Identification Test (AUDIT) on the Internet.

Results. The vast majority of the respondents drink alcohol $(80 \%-560$ people $)$, every fifth respondent declared abstinence $(20 \%-140$ respondents). The gender of the respondents significantly differentiated the level of alcohol consumption $\left(\chi^{2}=42.262 ; p<0.0001\right)$. More women than men consumed alcohol at a low risk of developing alcohol-related disorders $(89.04 \%$, i.e. 406 women $-71.72 \%$, i.e. $175 \mathrm{men})$. The value of BMI significantly differentiated the level of alcohol consumption $\left(\chi^{2}=17.513 ; p=0.008\right)$.

Conclusions. Most respondents consume alcohol at low-risk. Gender and BMI value significantly determine alcohol consumption. It is therefore extremely important to organize at universities cyclical preventive lectures on the harmful effects of alcohol consumption, highlighting its different impact on men and women. Physical activity plays a positive role in promoting health, even when at the same time unhealthy habits such as excessive alcohol consumption occur. Therefore, the possibility of participation in the university in the afternoon sports and recreation classes should be particularly promoted among students.

Keywords: alcohol consumption, students, AUDIT

\section{Streszczenie}

Wprowadzenie. Alkohol jest jednym z psychoaktywnych środków uzależniających obecnych w życiu studenta, a jego spożycie odnotowuje się na wysokim poziomie. Celem badań było określenie poziomu spożycia alkoholu przez studiujących w województwie lubelskim.

Materiał i metody. Badania przeprowadzono w 2018 roku wśród 700 studentów studiów I-go stopnia z województwa Lubelskiego (456 kobiet - 65,14\% i 244 mężczyzn - 34,86\%), którzy wypełnili przez Internet test Rozpoznawania Zaburzeń Związanych ze Spożywaniem Alkoholu (AUDIT).

Wyniki. Zdecydowana większość badanych pije alkohol (80\% - 560 osób), co piąty badany deklarował abstynencję $(20 \%$ - 140). Płeć ankietowanych istotnie różnicowała poziom spożycia alkoholu $\left(\chi^{2}=42,262 ; \mathrm{p}<0,0001\right)$. Więcej kobiet niż mężczyzn spożywało alkohol na niskim poziomie ryzyka wystąpienia zaburzeń związanych ze spożywaniem alkoholu $(89,04 \%$, tj. 406 kobiet - 71,72\%, tj. 175 mężczyzn). Wartość wskaźnika BMI różnicowała istotnie poziom spożycia alkoholu $\left(\chi^{2}=17,513 ; p=0,008\right)$.

Wnioski. Większość respondentów spożywa alkohol na niskim poziomie ryzyka. Płeći wartość wskaźnika BMI istotnie determinują spożywanie alkoholu. Jest zatem niezmiernie ważne, aby organizować na uczelniach wyższych cykliczne wykłady profilaktyczne na temat szkodliwych skutków spożywania alkoholu, podkreślając jego różny wpływ na organizmy kobiet i mężczyzn. Aktywność fizyczna odgrywa pozytywną rolę w promowaniu zdrowia, nawet wtedy, gdy jednocześnie pojawiają się niezdrowe nawyki, takie jak na przykład nadmierna konsumpcja alkoholu. Należy zatem szczególnie promować wśród studentów możliwość uczestnictwa na uczelni w popołudniowych zajęciach sportowo-rekreacyjnych.

Słowa kluczowe: spożycie alkoholu, studenci, AUDIT

Mandziuk M, Wasilewska M, Lukács A. Alcohol consumption among students in the Lublin region of Poland. Health Prob Civil. 2020; 14(1): 18-23. https://doi.org/10.5114/hpc.2020.92981

Address for correspondence / Adres korespondencyjny: Małgorzata Wasilewska, Pope John Paul II State School of Higher Education, Sidorska 95/97, 21-500 Biała Podlaska, Poland, e-mail: m.wasilewska@dydaktyka.pswbp.pl, phone: +48 833449900

ORCID: Marta Mandziuk https://orcid.org/0000-0003-1219-954X, Małgorzata Wasilewska https://orcid.org/0000-0003-4844-6477,

ORCID: Marta Mandziuk https://orcid.org/0000-0003-12
Andrea Lukács https://orcid.org/0000-0002-1938-8071

Copyright: (C) Pope John Paul II State School of Higher Education in Biała Podlaska, Marta Mandziuk, Małgorzata Wasilewska, Andrea Lukács. This is an Open Access journal, all articles are distributed under the terms of the Creative Commons Attribution-NonCommercial-ShareAlike 4.0 International (CC BY-NC-SA 4.0) License (http://creativecommons.org/licenses/by-nc-sa/4.0/), allowing third parties to copy and redistribute the material in any medium or format and to remix, transform, and build upon the material, provided the original work is properly cited and states its license. 


\section{Introduction}

Going to college is a time of many changes in the lives of young people. During this time the values and habits shaped during upbringing are tested. New social contacts, a different - irregular - lifestyle, moving away from home and associated stress lead to risky behavior in young people. The risky behaviors most commonly described in the literature for this age group include, first of all, the use of psychoactive substances (tobacco, alcohol, drugs), anti-social behavior, premature and risky sexual conduct [1, 2, 3, 4]. Early alcohol initiation and regular alcohol consumption increase the risk of becoming addicted or suffering from non-communicable diseases due to alcohol abuse. Factors that encourage alcohol consumption among young people are various. Social considerations (positive external motivation) dominate among the reasons for drinking alcohol as indicated by Cooper's motivation scale abbreviated by Kuntsche et al. [5]. Negative external motivation, i.e. the desire to fit into a group, was definitely the least selected choice. The subquestions show that young people turn to alcohol most frequently to have fun at parties, and least frequently not to feel rejected or disliked. The main motivator in the ranking is internal/personal reasons, i.e. the desire to get drunk or experience novel pleasant sensations. The most negative effects of alcohol consumption among young people include driving under the influence of alcohol, undertaking risky and/or unwanted sexual behavior, participating in fights, committing acts of vandalism. Since heavy drinking during early adulthood is widespread, many people see nothing wrong with these behaviors [6]. Easy access to alcoholic beverages, cultural behaviors, widespread advertising of alcoholic beverages cause the prevalence of its consumption not only among students but also more frequently among junior high school and high school students $[7,8,9]$. Some reports indicate an increasing number of young people who suffer from the symptoms of heavy drinking whilst attending college $[10,11,12]$. The aim of the study was to determine the level of alcohol consumption in students from the Lublin province.

\section{Material and methods}

As part of the "EurEcas - European assessment of behavior toward health and addiction among students" project (EurEcas - Europejska ocena zachowań wobec zdrowia oraz uzależnień wśród studentów) ${ }^{1}$, students from Hungary, Ukraine and Poland were surveyed in spring 2018. The "EurEcas" project was implemented utilizing funds for statutory activities as part of activities to maintain research potential during the period from 2017 to 2019 in Pope John Paul II State School of Higher Education in Biała Podlaska, Poland. 2,130 students took part in the project in total, however, after a preliminary analysis, incomplete answers were found in 165 of the responses. Finally, correctly completed questionnaires were obtained from 1965 students (542 from Hungary, 723 from Ukraine and 700 from Poland). Students agreed to participate in the study and completed a survey via the Internet. The survey consisted of the following questionnaires SCOFF, IFIS, DASS-21, LOT-R, AUDIT and additional questions. The questions concerned the place of residence during the time spent in college, the received scholarships, health and marital status of the students as well as their height and weight. It took the respondents about 30 minutes to complete the survey.

The results collected in this article used data from AUDIT regarding students from eastern Poland, the Lublin province ( 456 women $-65.14 \%$ and 244 men $-34.86 \%$ ). The respondents were freshmen between the ages of 19 and 23. The Alcohol Use Disorder Identification Test (AUDIT) developed by WHO is used to determine the harmful effects of alcohol consumption [1]. Alcohol consumption can be described in grams as the quantity of consumed alcohol or by using the so-called standard unit of alcohol (in Europe it is 10 grams of pure alcohol). Depending on the type of alcohol, a unit is $250 \mathrm{ml}$ of $5 \%$ beer, $100 \mathrm{ml}$ of $12 \%$ wine and $30 \mathrm{ml}$ of $40 \%$ vodka. The test contains 10 questions scored appropriately from 0 to 4 . Four levels of alcohol consumption were identified in AUDIT: drinking within the low risk of developing alcohol-related disorders, risky consumption, harmful drinking, and suspected alcohol dependence. Higher test scores indicate a higher probability of harmful alcohol consumption. Obtaining eight or more points in questions 1-3 indicates dangerous and risky alcohol consumption. The $\chi^{2}$ test was used in statistical analyses, establishing statistical significance at the level of $\mathrm{p}<0.05$.

\section{Results}

Among the surveyed population, every fifth student admitted that they were abstinent and did not consume alcohol (20\%, i.e. 140 people), while $80 \%$ of the respondents (560 people) consume alcoholic beverages with different frequency. Alcohol is consumed by 224 students (32\%) once a month or less, 252 of the study participants (36\%) drink 2-4 times a month, 70 respondents (10\%) drink 2-3 times a week, while 14 people (2\%) drink

\footnotetext{
${ }^{1}$ EurEcas - European assessment of behavior toward health and addiction among students. Statutory research to maintain the research potential in the years 2017-2019, No. S/17/17.
} 
more often than 4 times a week. During a typical day on which the respondents consume alcohol, $43.2 \%(242$ students) drink 1-2 units, 3-4 units - 35\% (196), 5-6-13\% (73), 7-8 units - 3.2\% (18), above 10 units - 5.6\% (31). When asked about the frequency of consuming more than six units of alcohol at a time, 42\% of the students (235) answered that they never exceed this amount. Every third student admitted that they drank more than six units of alcohol less than once a month $(31.5 \%-176)$, such a dose is consumed every day by $0.7 \%$ of the respondents $(7$ students). During the year preceding the survey, $7.6 \%$ of the students (43 people) were unable to stop drinking once they started. This happened less than once a month, and 5.7\% of the participants (32 respondents) were in this situation at least once a month. Over the last year, at least once a month, every tenth respondent needed at least one portion of alcohol the following morning after excessive alcohol consumption the previous day $(10.1 \%$ - 57 people). Memory problems were reported in 23.1\% (129) of the students who could not remember what they were doing the previous evening while they were consuming alcohol. This happened less than once a month. $10.1 \%$ of the respondents (129 people) declared memory problems after drinking alcohol once a month, and $5.5 \%$ (31 of the participants) experienced this problem once a week. Table 1 shows the distribution of alcohol consumption levels among the surveyed students. The vast majority of the respondents, both men and women, consumed alcohol within the low-risk of developing alcohol-related disorders. The gender of the respondents significantly differentiated the level of alcohol consumption among the students $\left(\chi^{2}=42.2262 ; \mathrm{p}<0.0001\right)$. More women than men consumed alcohol within the low-risk of developing alcohol-related disorders (406 women, i.e. $89.04 \%$ and 175 men, i.e. $71.72 \%$ ). The obtained results indicate that more men 5.33\% (13) than women $0.66 \%$ (3) drink alcohol within the level involving risk (19.26\% - 47 men; 9.86\% - 45 women). It has been observed that suspicion of alcohol dependence is more common in the case of men (3.69\% - 9 men; $0.44 \%-2$ women). A detailed analysis showed that the BMI value significantly differentiated the level of alcohol consumption $\left(\chi^{2}=17.513 ; p=0.008\right)$. Subjects who were overweight (26 people, i.e. $\left.17.81 \%\right)$ and those with the correct BMI value (65 people, i.e. 13.4\%) consumed alcohol within the level involving risk significantly more frequently than those who were underweight (1 person, i.e. $1.45 \%$ ).

Table 1. The level of alcohol consumption among the students

\begin{tabular}{|c|c|c|c|c|c|c|c|c|c|c|c|}
\hline \multirow{3}{*}{\multicolumn{2}{|c|}{ Differentiating factor }} & \multicolumn{10}{|c|}{ The level of alcohol consumption } \\
\hline & & \multicolumn{2}{|c|}{$\begin{array}{l}\text { Low level } \\
\text { of risk }\end{array}$} & \multicolumn{2}{|c|}{$\begin{array}{l}\text { Harmful } \\
\text { drinking }\end{array}$} & \multicolumn{2}{|c|}{$\begin{array}{c}\text { Risky } \\
\text { drinking }\end{array}$} & \multicolumn{2}{|c|}{$\begin{array}{l}\text { Suspected } \\
\text { alcohol } \\
\text { dependence }\end{array}$} & \multicolumn{2}{|c|}{ Total } \\
\hline & & $\mathbf{N}$ & $\%$ & $\mathbf{N}$ & $\%$ & $\mathbf{N}$ & $\%$ & $\mathbf{N}$ & $\%$ & $\mathbf{N}$ & $\%$ \\
\hline \multirow{2}{*}{$\begin{array}{c}\text { sex } \\
\chi^{2}=42.262 \\
p<0.0001^{*}\end{array}$} & male & 175 & 71.72 & 13 & 5.33 & 47 & 19.26 & 9 & 3.69 & 244 & 100 \\
\hline & female & 406 & 89.04 & 3 & 0.66 & 45 & 9.86 & 2 & 0.44 & 456 & 100 \\
\hline \multirow{3}{*}{$\begin{array}{c}\text { place of } \\
\text { residence during } \\
\text { college } \\
\chi^{2}=8.537 \\
\mathbf{p}=0.201 \\
\end{array}$} & renting & 270 & 81.33 & 8 & 2.41 & 48 & 14.46 & 6 & 1.81 & 332 & 100 \\
\hline & with parents & 255 & 82.26 & 8 & 2.58 & 42 & 13.55 & 5 & 1.61 & 310 & 100 \\
\hline & dormitory & 56 & 96.55 & 0 & 0 & 2 & 3.45 & 0 & 0 & 58 & 100 \\
\hline \multirow{2}{*}{$\begin{array}{c}\text { marital status } \\
\chi^{2}=1.579 \\
\mathbf{p}=0.664\end{array}$} & single & 334 & 83.08 & 10 & 2.49 & 50 & 12.44 & 8 & 1.99 & 402 & 100 \\
\hline & in a relationship & 247 & 82.89 & 6 & 2.01 & 42 & 14.09 & 3 & 1.01 & 298 & 100 \\
\hline \multirow{3}{*}{$\begin{array}{c}\text { year of study } \\
\chi^{2}=7.028 \\
p=0.318\end{array}$} & 1 & 327 & 84.72 & 7 & 1.81 & 46 & 11.92 & 6 & 1.55 & 386 & 100 \\
\hline & 2 & 138 & 82.14 & 7 & 4.17 & 20 & 11.9 & 3 & 1.79 & 168 & 100 \\
\hline & 3 & 116 & 79.45 & 2 & 1.37 & 26 & 17.81 & 2 & 1.37 & 146 & 100 \\
\hline \multirow{2}{*}{$\begin{array}{c}\text { being in college } \\
\text { and working } \\
\chi^{2}=1.107 \\
p=0.775\end{array}$} & yes & 123 & 82.56 & 2 & 1.34 & 21 & 14.09 & 3 & 2.01 & 149 & 100 \\
\hline & no & 458 & 83.12 & 14 & 2.54 & 71 & 12.86 & 8 & 1.48 & 551 & 100 \\
\hline \multirow{2}{*}{$\begin{array}{c}\text { scholarship } \\
\chi^{2}=3.837 \\
p=0.279\end{array}$} & yes & 377 & 84.72 & 8 & 1.8 & 55 & 12.36 & 5 & 1.12 & 445 & 100 \\
\hline & no & 204 & 80 & 8 & 3.14 & 37 & 14.51 & 6 & 2.35 & 255 & 100 \\
\hline \multirow{3}{*}{$\begin{array}{c}\text { BMI } \\
\chi^{2}=17.513 \\
p=0.008\end{array}$} & underweight & 68 & 98.55 & 0 & 0 & 1 & 1.45 & 0 & 0 & 69 & 100 \\
\hline & normal & 401 & 82.68 & 10 & 2.06 & 65 & 13.4 & 9 & 1.86 & 485 & 100 \\
\hline & $\begin{array}{l}\text { obesity / } \\
\text { overweight }\end{array}$ & 112 & 76.71 & 6 & 4.11 & 26 & 17.81 & 2 & 1.37 & 146 & 100 \\
\hline
\end{tabular}

*significance level of $\mathrm{p}<0.05$ 


\section{Discussion}

Alcohol consumption is associated with the risk of physical health loss and it can also lead to mental and social disorders. WHO states in the 2019 report that alcohol consumption in the European region, including the EU, is the highest in the world, which may result in an increased incidence of non-communicable diseases. The study results showed a slight decrease in alcohol consumption in 2016 compared to 2010 (11.5-11.3 liters of pure alcohol per person).

In the EU countries, the percentage of alcohol consumption decreased from $78.6 \%$ in 2010 to $75.9 \%$ in 2016 in the 20-24 age group [23]. According to data from the Central Statistical Office [17], in 2014 the percentage of alcohol users aged between 15 and 29 decreased compared to 2009 (from $71.5 \%$ to 69.1\%) and the percentage of people declaring abstinence increased (2009 - 28.5\%; $2014-30.9 \%)$. Study results obtained on a group of over 9,000 students of Polish universities at the request of PARPA indicate high alcohol consumption in this age group. $75 \%$ of students consumed alcohol at least once in the month preceding the study, three or more times a month - almost 44\% [8]. The problem of high alcohol consumption by students exists not only in Poland but also in other countries, which is confirmed by the results of other studies $[9,10,11,13,14,15,16,24]$. The results of our research confirm these observations. Most respondents 80\% (560 people) drink alcohol, while $20 \%$ (140 people) declared abstinence. Kurpas and colleagues previously reported a significantly smaller percentage of non-drinkers among the students of the Medical University of Wroclaw - 3.79\% [15]. Binkowska-Bury et al. arrived at similar conclusions among the freshmen from Rzeszów universities - 4.7\% [22]. The results of the presented research regarding the number of units of alcohol consumed during a typical day are similar to those of other authors. One or two units are consumed by $43.3 \%$ of the surveyed students, a slightly higher percentage of students consuming the same amount of alcohol was recorded among the students of the Medical University of Wrocław - 47.41\% [15], students in Lublin - 48\% [21] and among medical university students - 55\% [11]. Every third student at the Faculty of Medicine at the Medical University of Bialystok consumed one or two units of alcohol $-34.4 \%$ [18]. Similar results to the results of our study were observed in the case of students consuming of three or four units at a time $-34.8 \%$ of the respondents, $28.16 \%$ [15], 37.1\% [18], 26\% [11], 22.8\% [22]. The consumption of five or six units of alcohol was recorded among $13 \%$ of the respondents, while in the studies of Kurpas et al. - 11.49\% [15] and 9.8\% [11]. 5.6\% of the respondents consume more than ten units of alcohol, similar results were obtained by other researchers - 6.15\% [16], 5.9\% [19], 4\% [12].

The prevalence of alcohol consumption among students is high, men are more likely to declare the consumption of this type of substance. An analysis of our research results showed that gender is a factor that significantly differentiates the level of alcohol consumption, which is consistent with the results of other authors $[9,15,18,19$, 20]. The results of AUDIT suggest that in the case of the majority of the respondents the current model of alcohol consumption is within the low-risk level (89.04\% - 406 women; 71.72\% - 175 men). Alcohol consumption that is risky to health was reported by more male students than female students $(19.26 \%-47$ men and $9.86 \%-45$ women). $17.7 \%$ of students from Rzeszów universities consumed alcohol within the level involving risk [22]. Risky drinking correlated with gender and was more common in men in the studies of Kurpas et al. $\left(\mathrm{r}_{\mathrm{s}}=0.166\right.$; $\mathrm{p}<0.001$ ) [15].

Going to college very often involves a change of residence, leaving the family home to live in a dormitory or a rented place. In the conducted study, no statistically significant differences were found between the place of residence during college time and the level of alcohol consumption among the students. Such a relationship was also not found among the students at the Medical University of Wrocław ( $>>0.05)$ [15]. Different results were obtained in studies involving Irish students $(p<0.001)$ [14]. In the cited studies, the value of BMI did not significantly differentiate the level of alcohol consumption $(p=0.96$ for women and $p=0.97$ for men), while this correlation was evident in our research results $\left(\chi^{2}=17.513 ; p=0.008\right)$.

\section{Conclusions}

Alcohol is an inseparable part of student life, however, it is very important to control the frequency and amount of alcohol consumption. Not everyone who drinks alcohol is addicted but even a single dose is a health risk.

1. Most respondents, both men and women, consume alcohol within the low-risk level of developing alcoholrelated disorders and gender significantly differentiates the level of alcohol consumption, men drink more often.

2. The problem of alcohol abuse among students prompts us to take preventive actions, the need for which has recently been highlighted in our country. It is therefore extremely significant to organize cyclical 
preventive lectures on the harmful effects of alcohol consumption at universities, highlighting the impact of alcohol on the bodies of women and men.

3. Students are often away from home, they tend to lead a different - irregular - lifestyle, often associated with irregular, poorly balanced nutrition, which can lead to being overweight or underweight. It should be emphasized that it was overweight study participants who consumed alcohol within the level involving risk more frequently. Therefore, in order to improve the quality of life of students with an incorrect BMI, it is necessary to intensify their motivation to participate in afternoon sports and recreation activities. It should be noted that physical activity plays a positive role in promoting health, even if unhealthy habits, such as excessive alcohol consumption, appear at the same time [25]. Currently, many universities in the Lublin province offer a wide range of extracurricular physical activities, such as wall climbing, indoor rowing for men and women, fitness, volleyball, football, table tennis, weight training, badminton, futsal, and many others. Such classes not only increase the level of physical activity amongst students in their free time, but they also contribute to meeting the recommendations of the recommended weekly dose of physical activity while reducing the negative effects of excessive alcohol consumption.

4. The aim of these initiatives is, among others, to reach out to students who abuse alcohol and help them. It is also expedient to conduct systematic research on the prevalence of alcohol abuse among students and on their beliefs and expectations related to the effects of alcohol.

\section{Disclosures and acknowledgements}

The manager of the "EurEcas - European assessment of behavior toward health and addiction among students" project was the late Professor Józef Bergier. He will be remembered not only as a great promoter of research on health behavior but also as a tireless originator and advocate of new scientific challenges.

\section{References:}

1. Barbor TF, Higgins-Biddle JC, Saunders JB, Monteiro MG. AUDIT: the Alcohol Use Disorders Identification Test: guidelines for use in primary care. Second Edition [Internet]. Geneva: WHO; 2001 [cited 2018 Jul 25]. Available from: http://www.who.int/substance_abuse/publications/audit/en/

2. Klimberg A, Marcinkowski JT, Przybylski J. [Consumption of alcohol and other psycho-active substances among the students of selected medical university faculties. Part III. The causes, circumstances and effects of alcohol consumption]. Problemy Higieny i Epidemiologii. 2009; 90(1): 47-54 (in Polish).

3. Kowalewski I. [Students' health culture. Diagnosis and perspectives]. Kraków: Wydawnictwo Naukowe Akademii Pedagogicznej; 2006 (in Polish).

4. Zadworna-Cieślak M. [The role of the family in shaping risky health behaviors of the youth]. In: OgińskaBulik N., editor. [Risky and harmful health behaviors]. Łódź: Wydawnictwo Akademii HumanistycznoEkonomicznej w Łodzi; 2010 (in Polish).

5. Mazur J. [Motives for drinking alcohol and problematic behavior of the youth]. Remedium - Profilaktyka problemowa i promocja zdrowia psychicznego. 2013; February (in Polish).

6. Chodkiewicz J. [Alcohol drinking and knowledge about alcohol abuse among students of two Łódź academies]. Alkoholizm i Narkomania. 2006; 19(2): 107-119 (in Polish).

7. Nazarko K, Bielska D. [Drinking alcohol - a frequent risk behaviour among upper secondary school students]. Przegląd Lekarski. 2012; 69(10): 878-883 (in Polish).

8. www.parpa.pl [Internet]. Warszawa: Państwowa Agencja Rozwiązywania Problemów Alkoholowych. ["Students 2000" Research Results] [cited 2018 Jul 25]. Available from: http://www.parpa.pl/index.php/ art/858-wyniki-badan-studenci-2000 (in Polish).

9. Szczerbiński R, Karczewski J. [Selection of dietary behaviors among students of College of Physical Education and Tourism in Supraśl - cigarette smoking and alcohol drinking]. Hygeia Public Health. 2010; 45(2): 185188 (in Polish).

10. Gembalczyk I. [Alcohol as an element of students' lifestyle]. Roczn. PZH. 2006; 57(Suppl.): 101-105 (in Polish).

11. Kurpas D, Mroczek B, Bielska D, Wojtal M, Seń M, Steciwko A. [Alcohol consumption and tobacco smoking among medical university students]. Przegląd Lekarski. 2012; 69(10): 893-895 (in Polish).

12. Rybowska A, Nazarewicz R, Babicz-Zielińska E. [Model of alcohol consumption among university students]. Żywienie Człowieka i Metabolizm. 2003; 30: 423-427 (in Polish).

13. Brancković S, Pilav A, Cilović-Lagarija S, Pasalić A, Mahmutović J. Lifestyles of university students in Bosnia and Herzegovina. Journal of Health Sciences. 2017; 7(1): 27-34. https://doi.org/10.17532/jhsci.2017.441 
14. Davoren MP, Shiely F, Byrne M, Perry IJ. Hazardous alcohol consumption among university students in Ireland: a cross-sectional study. BMJ Open. 2015; 5: e006045. https://doi.org/10.1136/bmjopen-2014-006045

15. Kurpas D, Mroczek B, Bielska D, Wojtal M, Grata-Borkowska U, Hans-Wytrychowska A, et al. [Level of alcohol intake and tobacco smoking among students of Wroclaw Medical University]. Problemy Higieny i Epidemiologii. 2013; 94(4): 757-761 (in Polish).

16. Lukács A, Simon N, Demeter J, Kiss Danyi E, Kiss-Toth E. Alcohol consumption among university students. Egeszsegtudomanyi Kozlemenyek. 2013; 57-61.

17. www.stat.gov.pl [Internet]. Warsaw: Statistics Poland; 2017. [Statistical yearbook of the Republic of Poland 2017] [cited 2018 Aug 2]. Available from: http://stat.gov.pl/obszary-tematyczne/roczniki-statystyczne/ roczniki-statystyczne/rocznik-statystyczny-rzeczypospolitej-polskiej-2017,2,17.html (in Polish).

18. Bielska D, Kurpas D, Marcinkowicz L, Owłasiuk A, Litwiejko A, Wojtal M. [Alcohol consumption and tobacco smoking risk assessment among $4^{\text {th }}$ year students of Faculty of Medicine]. Przegląd Lekarski. 2012; 69(10): 900-903 (in Polish).

19. Brutovska M, Orosova O, Kalina O. Gender, normative beliefs and alcohol consumption among university students. In: Pracana C., editor. Psychology Applications \& Developments. Lisbon: Portuguese Association of Psychoanalysis and Psychoanalytic Psychotherapy; 2016. pp. 67-75.

20. Rogowska AM. [Prevalence of psychoactive substance use in college students]. Problemy Higieny i Epidemiologii. 2015; 96(1): 232-239 (in Polish).

21. Przybylska D, Borzęcki A, Szczerba W. [Alcohol and nicotine problem among medical university students in Lublin]. Forum Medycyny Rodzinnej. 2015; 9(3): 203-205 (in Polish).

22. Binkowska-Bury M, Więch P, Sałacińska I, Januszewicz P. [Alcohol consumption among first year Rzeszow’s universities students]. Problemy Pielęgniarstwa. 2014; 22(3): 246-251 (in Polish).

23. Survey conducted by TNS Opinion \& Social at the request of Directorate General Health and Consumers. EU citizens' attitudes towards alcohol. Eurobarometer 72.3 [Internet]. Brussels: TNS Opinion \& Social; 2010 [cited 2020 Jan 3]. Available from: https:/ec.europa.eu/health/sites/health/files/alcohol/docs/ebs_331_en.pdf

24. Cooke R, Beccaria F, Demant J, Fernandes-Jesus M, Fleig L, Negreiros J, et al. Patterns of alcohol consumption and alcohol-related harm among European university students. European Journal of Public Health. 2019; 29(6): 1125-1129. https://doi.org/10.1093/eurpub/ckz067

25. Perreault K, Bauman A, Johnson N, Britton A, Rangul V, Stamatakis E. Does physical activity moderate the association between alcohol drinking and all-cause, cancer and cardiovascular diseases mortality? A pooled analysis of eight British population cohorts. British Journal of Sports Medicine. 2017; 51: $651-657$. http://dx.doi.org/10.1136/bjsports-2016-096194 